\title{
Studi Perubahan Garis Pantai Tahun 2014-2019 di Pesisir Kabupaten Bantul, D.I. Yogyakarta
}

\author{
Putu Suryaniti Dewi ${ }^{1 *}$, Heryoso Setiyono ${ }^{1}$, Gentur Handoyo ${ }^{1}, \operatorname{Sugeng}_{\text {Widada }}{ }^{1}$ dan Agus Anugroho \\ Dwi Suryoputro ${ }^{1}$
}

\author{
Departemen Oseanografi, Fakultas Perikanan dan Ilmu Kelautan, Universitas Diponegoro \\ Jl. Prof. H. Soedarto, S.H, Tembalang, Semarang, Jawa Tengah. 50275 Indonesia \\ *Email : suryanitidewi@gmail.com
}

\begin{abstract}
Abstrak
Perubahan garis pantai dapat terjadi secara lambat maupun cepat bergantung pada faktor alami maupun aktivitas manusia yang mempengaruhi. Sebelah selatan Pesisir Kabupaten Bantul berbatasan langsung dengan Samudera Hindia dan dipengaruhi oleh gelombang yang dibangkitkan oleh angin. Kondisi pesisir dipengaruhi oleh gelombang angin memiliki potensi terjadinya perubahan garis pantai akibat abrasi maupun akresi. Tujuan dilakukan penelitian Studi Perubahan Garis Pantai Tahun 2014-2019 di Pesisir Kabupaten Bantul, D.I. Yogyakarta adalah untuk mengetahui luas perubahan garis pantai tahun 2014, 2017 dan 2019 hasil interpretasi citra Satelit Landsat 8. Metode kuantitatif deskriptif digunakan dengan analisis perhitungan statistik Digital Shoreline Analysis System (DSAS). Data penelitian yang digunakan antara lain kelerengan pantai lapangan pada tanggal 30 Januari 2020, data pasang surut yang diterbitkan oleh BIG, data angin dari laman ECMWF, data gelombang yang diterbitkan oleh BMKG Pusat dan digitasi garis pantai tahun 2014, 2017 dan 2019. Hasil penelitian menunjukkan bahwa tahun 2014-2017 luas abrasi lebih besar dengan luas 27,159 ha dibandingkan dengan luas akresi dengan luas 18,629 ha. Hasil penelitian untuk tahun 2017-2019 luas abrasi juga lebih besar dengan luas 21,903 ha dibandingkan dengan luas akresi seluas 14,835 ha.
\end{abstract}

Kata Kunci: Garis Pantai, Landsat 8, DSAS, Abrasi/Akresi, Pesisir Bantul

\begin{abstract}
Shoreline changes can occur slowly or quickly depends on natural and anthropogenic factors. South of the coast of Bantul Regency is bordered directly by the Indian Ocean and affected by waves generated by the wind. Coastal conditions that affected by wind waves have the potential for shoreline changes due to abrasion or accretion. The purpose of this Study of Shoreline Changes in 2014-2019 on The Coast of Bantul Regency, D.I. Yogyakarta is to determine the extent of shoreline changes in 2014, 2017 and 2019 as results of interpretation of Landsat 8 Satellite imagery. Descriptive quantitative methods were used with statistical analysis calculations for the Digital Shoreline Analysis System (DSAS). The research data used include coastal slope on 30 January 2020, tidal data published by BIG, wind data from the ECMWF website, wave data published by BMKG and shoreline digitization in 2014, 2017 and 2019. The results showed that in 2014-2017 the area of abrasion was greater by 27.159 ha compared with area of accretion by 18.629 ha. In 2017-2019 abrasion area is also greater with an area of 21,903 ha compared with an accretion area of 14,835 ha.
\end{abstract}

Keywords: Shoreline, Landsat 8, DSAS, Abrasion/Accretion, Bantul Coast

\section{PENDAHULUAN}

Garis pantai memiliki pengertian sebagai suatu garis atau batas antara daratan dengan lautan yang memiliki posisi tidak tetap (Triatmodjo, 1999). Posisi garis pantai yang tidak tetap mengakibatkan terjadinya perubahan garis pantai. Perubahan pada garis pantai dapat dilihat dari maju atau mundurnya garis pantai yang diakibatkan oleh aktivitas manusia maupun fenomena alam (Halim et al., 2016). Hidayat (2005), menyatakan bahwa gelombang angin memiliki energi yang mampu mempengaruhi bentuk serta kelerengan pantai apabila menghantam pesisir yang mengakibatkan kelerengan semakin tergerus atau curam. Kelerengan yang semakin tergerus akan menyebabkan garis pantai semakin mundur, begitu pula sebaliknya. Selain gelombang, kondisi pasang surut yang dinamis juga mempengaruhi kondisi garis pantai. Faktor fenomena alam ini yang kemudian akan diteliti dan dibahas 
lebih lanjut pengaruhnya terhadap perubahan garis pantai.

Kabupaten Bantul merupakan salah satu kabupaten yang terletak di daerah pesisir dengan kawasan pantai di sebelah Selatan. Letak astronomis dari Kabupaten Bantul yaitu pada posisi 70 44' 04', - 80 00'27' Lintang Selatan dan 1100 12'34" - 1100 31' 08' Bujur Timur dengan luas wilayah 50.685 ha atau sekitar 61,96\% dari luas wilayah Provinsi Daerah Istimewa Yogyakarta (Badan Pusat Statistik Kabupaten Bantul, 2018). Kabupaten Bantul memiliki panjang garis pantai sekitar 15,65 km. Pantai di Kabupaten Bantul dipengaruhi oleh adanya gelombang yang dibangkitkan oleh angin sehingga berdampak pada terjadinya abrasi maupun akresi terhadap garis pantai.

Perubahan garis pantai yang terjadi di pesisir Kabupaten Bantul mampu mempengaruhi kegiatan yang ada di daerah pesisir, seperti pemukiman warga maupun aktivitas wisata. Perubahan garis pantai ini diakibatkan oleh posisi daerah pesisir Kabupaten Bantul yang berada di bagian selatan Pulau Jawa dan berbatasan langsung dengan Samudera Hindia, sehingga mengalami dampak dari energi gelombang laut yang menghantam pesisir. Energi gelombang tersebut dapat mempengaruhi kelerengan serta bentuk pantai dan mengakibatkan maju atau mundurnya garis pantai di lokasi penelitian. Penelitian mengenai perubahan garis pantai untuk mengetahui nilai abrasi dan akresi yang terjadi sangat penting untuk dilakukan. Pendekatan yang digunakan adalah pendekatan spasial Citra Landsat 8 OLI (Operational Land Imager) dengan metode DSAS. Selain itu, dilakukan juga pengolahan data kelerengan pantai berdasarkan penelitian lapangan, gelombang, angin, serta pasang surut yang digunakan untuk membahas hubungan antara perubahan garis pantai dengan faktor hidro-oseanografi yang terjadi.

Penelitian ini bertujuan untuk mengetahui luas perubahan garis pantai yang terjadi di pesisir Kabupaten Bantul dalam kurun waktu 2014, 2017 dan 2019 hasil interpretasi Citra Satelit Landsat 8. Sehingga informasi ini dapat memberi manfaat kepada instansi terkait yang berada di Kabupaten Bantul untuk dijadikan pertimbangan dan pengambilan keputusan dalam pembangunan bangunan pantai maupun pemanfaatan lahan yang ada di pesisir Kabupaten Bantul.

\section{MATERI DAN METODE}

Materi yang digunakan dalam penelitian berupa data kelerengan pantai yang diukur di 5 (lima) titik lokasi pengamatan lapangan serta Citra Satelit Landsat 8 OLI/TIRS path/row 120/65 tahun perekaman 2014, 2017 dan 2019. Data sekunder yang digunakan antara lain Data Pasang Surut tahun 2019 dari Badan Informasi Geospasial, Data Angin ECMWF (European Centre for Medium-Range Weather Forecasts) tahun 2018-2019, Data Ketinggian dan Periode Gelombang dari Badan Meteorologi Klimatologi dan Geofisika Pusat serta Peta Rupa Bumi Indonesia. Metode yang digunakan adalah metode kuantitatif yang bersifat deskriptif.

Pengambilan data kelerengan di beberapa titik pengamatan bertujuan untuk mengetahui klasifikasi lokasi penelitian yang berdampak kepada kondisi garis pantai dan dipengaruhi oleh gelombang angin yang merambat ke pesisir. Pengolahan data pasang surut menggunakan metode Admiralty untuk memperoleh nilai komponen dan tipe pasang surut yang disajikan berupa grafik pasang surut untuk analisa kondisi pasang surut di lokasi penelitian. Data angin diolah dengan perangkat lunak WR. Plot View untuk memperoleh mawar angin dalam skala Beaufort tiap musim kemudian digunakan untuk analisa kecepatan dan arah angin terhadap ketinggian gelombang yang merambat menuju pesisir. Data ketinggian dan periode gelombang dianalisis dengan metode penentuan gelombang representatif dan disajikan dalam bentuk tabel nilai tiap musim dalam satu tahun. Hasil ini digunakan dalam analisa ketinggian gelombang terhadap perubahan garis pantai yang terjadi.

\section{HASIL DAN PEMBAHASAN}

\section{A. Kelerengan Pantai}

Pengukuran kelerengan pantai dengan menggunakan kompas geologi dilakukan pada 5 titik pengamatan dengan 3 kali pengukuran di daerah garis pantai. Titik pengamatan mewakili 5 pantai yang terdapat di Kabupaten Bantul, antara lain Titik A di Pantai Parangtritis, Titik B di Pantai Parangkusumo, Titik C di Pantai Depok, Titik D di Pantai Samas dan Titik E di Pantai Kuwaru yang diklasifikasikan dengan klasifikasi Van Zuidam (1985). Nilai kelerengan pantai yang diperoleh dari pengamatan 
lapangan dari 5 titik pengamatan didapatkan 4 titik pengamatan diklasifikasikan sedikit curam dan 1 titik pengamatan diklasifikasikan curam. Hasil pengukuran disajikan pada Tabel 1 berikut ini

Tabel 1. Nilai Pengukuran Kelerengan Pantai

\begin{tabular}{|c|c|c|c|c|c|}
\hline \multirow{2}{*}{$\begin{array}{l}\text { Koordinat/ } \\
\text { Titik } \\
\text { Pengamatan }\end{array}$} & \multicolumn{4}{|c|}{ Nilai Kelerengan Pantai $\left({ }^{\circ}\right)$} & \multirow[b]{2}{*}{ Keterangan } \\
\hline & $\begin{array}{c}\text { Pengukuran } \\
1\end{array}$ & $\begin{array}{c}\text { Pengukuran } \\
2\end{array}$ & $\begin{array}{c}\text { Pengukuran } \\
3\end{array}$ & $\begin{array}{l}\text { Rata- } \\
\text { Rata }\end{array}$ & \\
\hline \multicolumn{6}{|c|}{$-8^{\circ} 01,630^{\prime} \mathrm{S} / 110^{\circ} 20,130^{\prime} \mathrm{E}$ (Pantai Parangtritis) } \\
\hline A & 5 & 8 & 8 & 7 & $\begin{array}{l}\text { Sedikit } \\
\text { Curam }\end{array}$ \\
\hline \multicolumn{6}{|c|}{$-8^{\circ} 01,437^{\prime} \mathrm{S} / 110^{\circ} 19,482^{\prime} \mathrm{E}$ (Pantai Parangkusumo) } \\
\hline B & 6 & 7,5 & 8 & 7,2 & $\begin{array}{l}\text { Sedikit } \\
\text { Curam }\end{array}$ \\
\hline \multicolumn{6}{|c|}{$-8^{\circ} 0,857^{\prime} \mathrm{S} / 110^{\circ} 17,563^{\prime} \mathrm{E}$ (Pantai Depok) } \\
\hline $\mathrm{C}$ & 12 & 13 & 12,5 & 12,5 & Curam \\
\hline \multicolumn{6}{|c|}{$-8^{\circ} 0,360^{\prime} \mathrm{S} / 110^{\circ} 15,981^{\prime} \mathrm{E}$ (Pantai Samas) } \\
\hline $\mathrm{D}$ & 6 & 5 & 8 & 6,3 & $\begin{array}{l}\text { Sedikit } \\
\text { Curam }\end{array}$ \\
\hline \multicolumn{6}{|c|}{$-7^{\circ} 59,454^{\prime} \mathrm{S} / 110^{\circ} 13,570^{\prime}$ E (Pantai Kuwaru) } \\
\hline E & 6 & 8 & 7 & 7 & $\begin{array}{l}\text { Sedikit } \\
\text { Curam }\end{array}$ \\
\hline
\end{tabular}

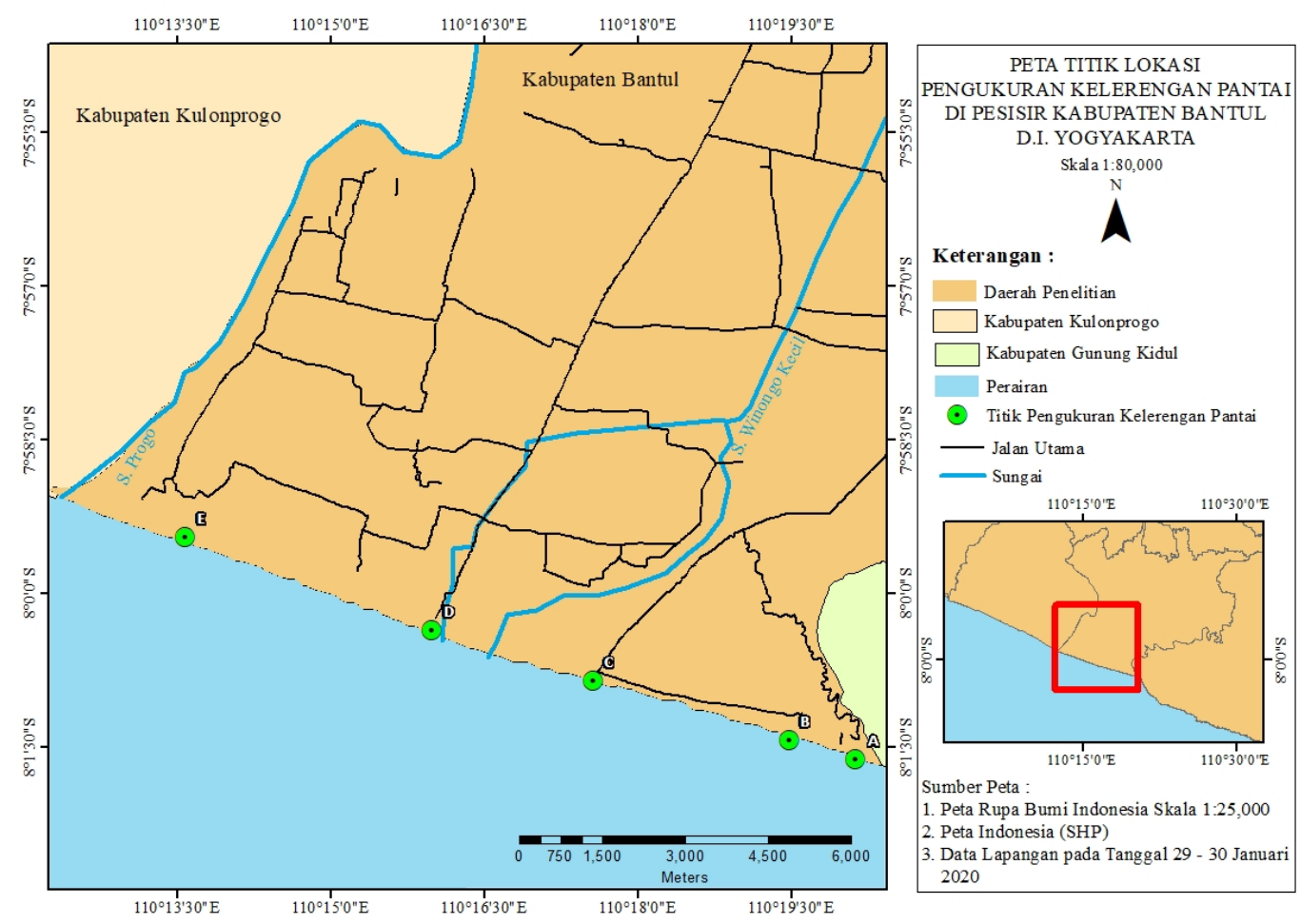

Gambar 1. Peta Titik Lokasi Pengukuran Kelerengan Pantai

\section{B. Pasang Surut}

Data pasang surut yang diperoleh dari Badan Informasi Geospasial diolah dengan metode Admiralty dan ditampilkan dalam bentuk grafik elevasi pasang surut masing-masing musim dalam tahun 
2019 (Gambar 2 - Gambar 5) serta nilai komponen pasang surut seperti nilai Formzahl untuk menentukan tipe pasang surut, LLWL, MSL dan HHWL (Tabel 2).

Tabel 2. Nilai Komponen Pasang Surut

\begin{tabular}{ccccc}
\hline & $\begin{array}{c}\text { Nilai } \\
\text { Formzahl }\end{array}$ & $\begin{array}{c}\text { LLWL } \\
(\mathrm{cm})\end{array}$ & $\begin{array}{c}\text { MSL } \\
(\mathrm{cm})\end{array}$ & $\begin{array}{c}\text { HHWL } \\
(\mathrm{cm})\end{array}$ \\
\hline Musim Barat & 4,046 & 0,100 & 37,358 & 113,500 \\
Musim Peralihan I & 4,755 & 0,200 & 36,462 & 107,500 \\
Musim Timur & 3,803 & 0,100 & 36,883 & 106,400 \\
$\begin{array}{c}\text { Musim Peralihan } \\
\text { II }\end{array}$ & 5,050 & 0,000 & 39,869 & 116,200 \\
\hline
\end{tabular}

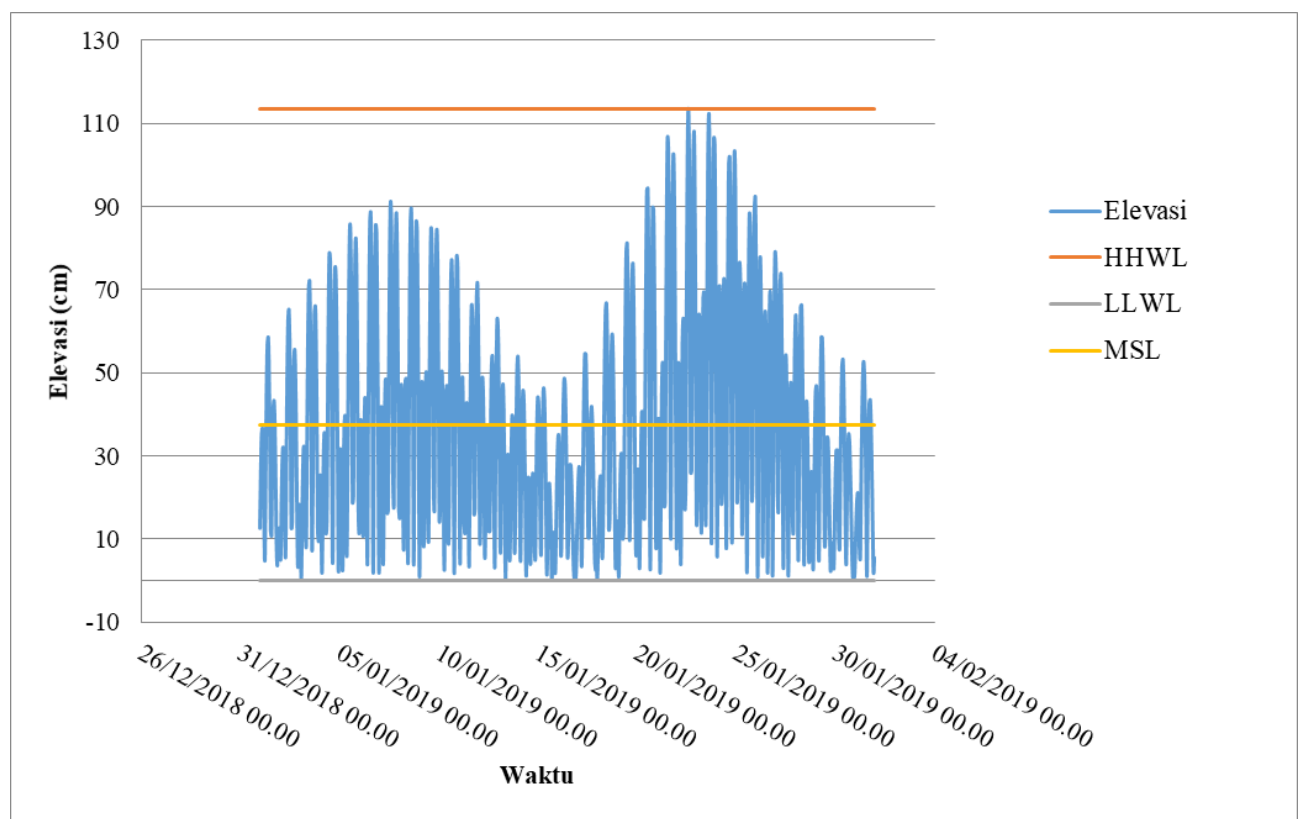

Gambar 2. Grafik Pasang Surut Musim Barat Tahun 2019

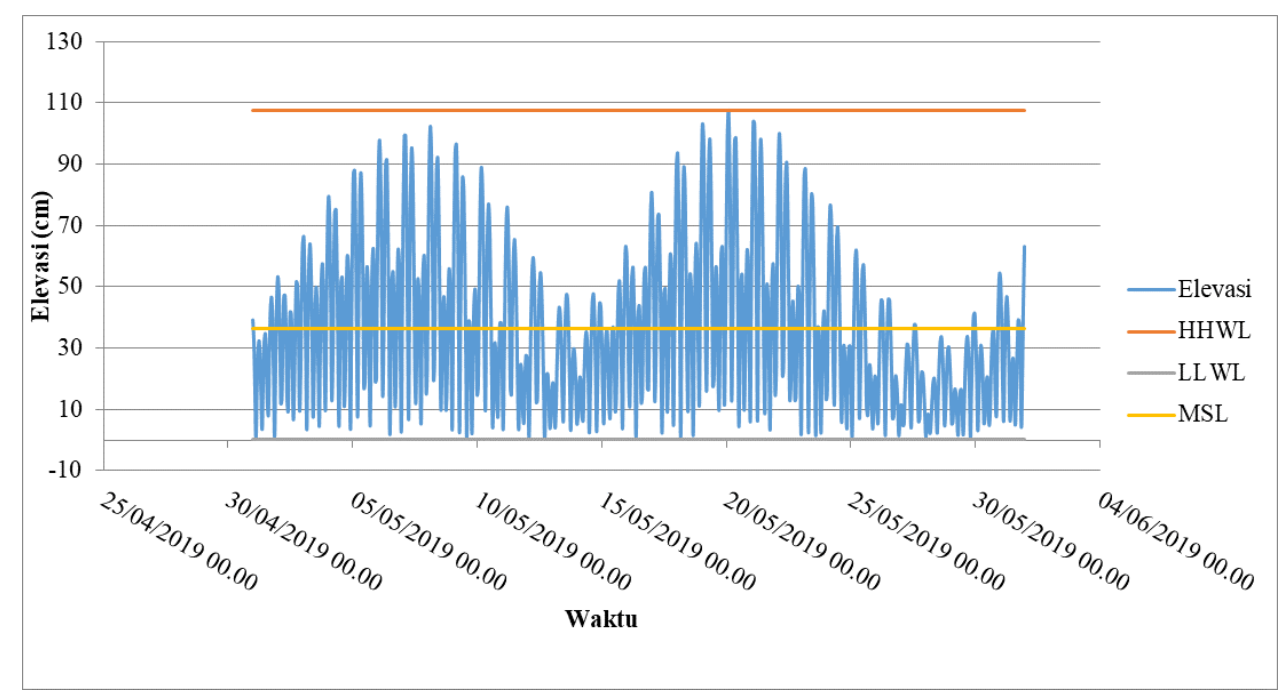

Gambar 3. Grafik Pasang Surut Musim Peralihan I Tahun 2019 
Grafik elevasi pasang surut Musim Barat tahun 2019 ditunjukkan pada Gambar 2. Nilai Formzahl, LLWL, MSL dan HHWL secara berturut-turut adalah 4,046; 0,100 cm; 37,358 cm dan $113,500 \mathrm{~cm}$. Gambar 3 menunjukkan grafik pasang surut Musim Peralihan I dengan nilai komponen bilangan Formzahl, LLWL, MSL dan HHWL berturut-turut adalah 4,755; 0,200 cm; 36,462 cm dan 107,500 cm.

Grafik pasang surut Musim Timur tahun 2019 ditunjukkan pada Gambar 4, dengan nilai Formzahl sebesar 3,803, LLWL sebesar 0,100 cm, MSL sebesar 36,883 cm serta nilai HHWL sebesar 106,400 cm. Pasang surut Musim Peralihan II ditunjukkan pada Gambar 5, nilai Formzahl, LLWL, MSL dan HHWL secara berturut-turut sebesar 5,050;0,000 cm; 39,869 cm dan 116,200 cm.

Tipe pasang surut dapat ditentukan dengan Nilai Formzahl yang diperoleh dari metode Admiralty. Nilai Formzahl yang diperoleh lebih besar dari $3 \quad(\mathrm{~F} \geq 3)$, yaitu tipe pasang surut harian tunggal (Triatmodjo, 1999).

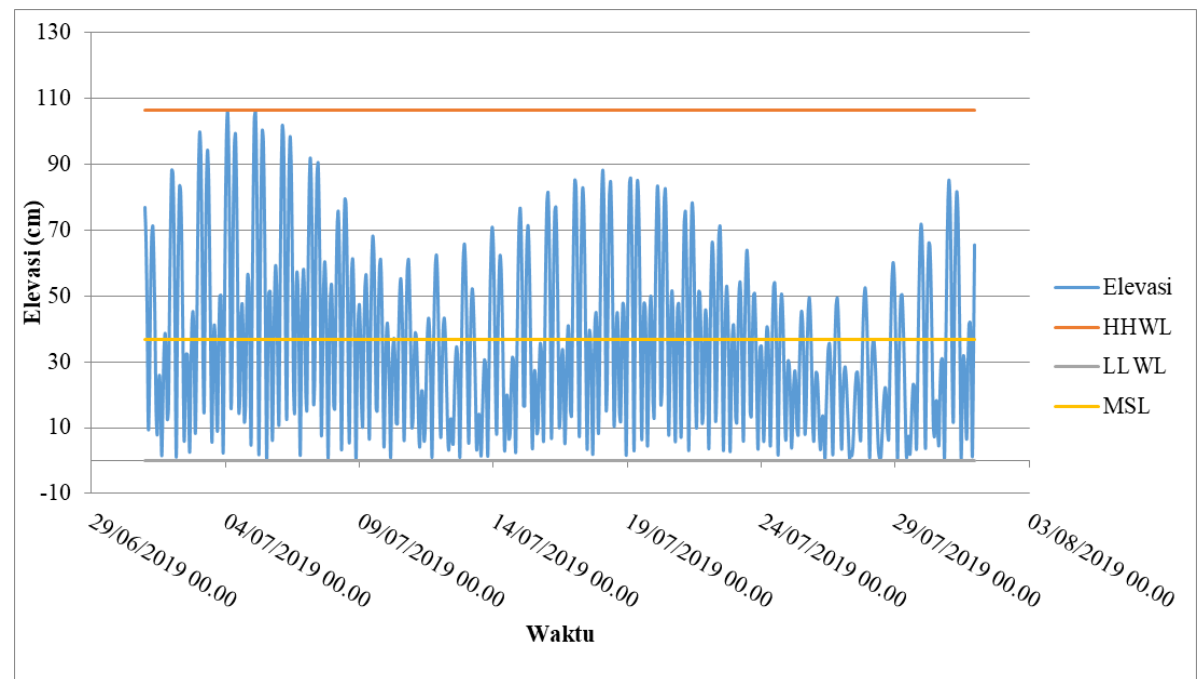

Gambar 4. Grafik Pasang Surut Musim Timur Tahun 2019

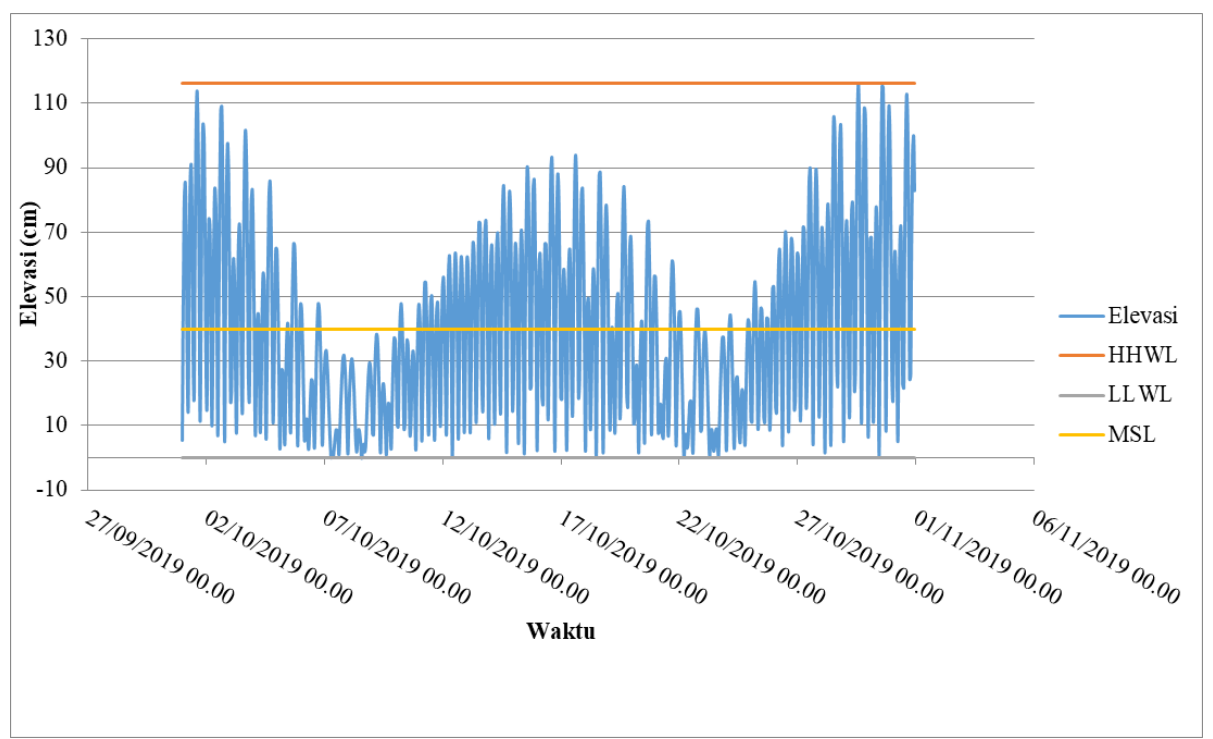

Gambar 5. Grafik Pasang Surut Musim Peralihan II Tahun 2019

\section{Angin}

Data angin disajikan dengan mawar angin mengacu kepada skala Beaufort dalam 8 arah mata angin. Berdasarkan skala tersebut acuan angin sebagai pembangkit gelombang memiliki nilai kecepatan 
angin $>5,5 \mathrm{~m} / \mathrm{s}$ (Stewart, 2008). Mawar angin Musim Barat tahun 2018-2019 menunjukkan bahwa arah Timur Laut, Timur, Tenggara, Selatan, Barat Daya, dan Barat memiliki nilai kecepatan angin pembangkit gelombang sebesar 0\%. Arah Utara memiliki kecepatan 5.5-8.0 m/s sebesar 3.97351\% dan kecepatan $>8.0 \mathrm{~m} / \mathrm{s}$ sebesar 0\%. Arah Barat Laut memiliki kecepatan angin 5.5-8.0 m/s sebesar $47.0199 \%$ dan kecepatan angin $>8.0 \mathrm{~m} / \mathrm{s}$ sebesar $1.98675 \%$. Arah resultan kecepatan angin yaitu arah Barat Laut ( $318^{\circ} \mathrm{E}$ ), dengan frekuensi kecepatan angin pembangkit gelombang dan kecepatan angin total terbesar adalah arah Barat Laut dengan nilai berturut-turut yaitu $49.00665 \%$ dan 92.053\%.

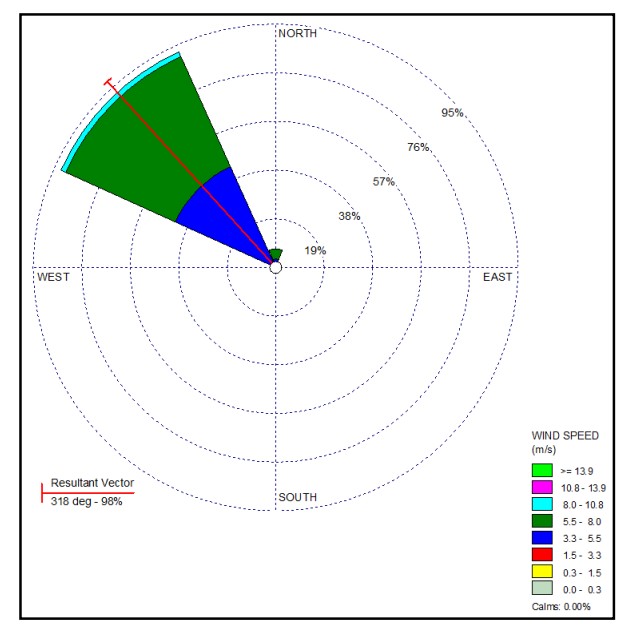

a.

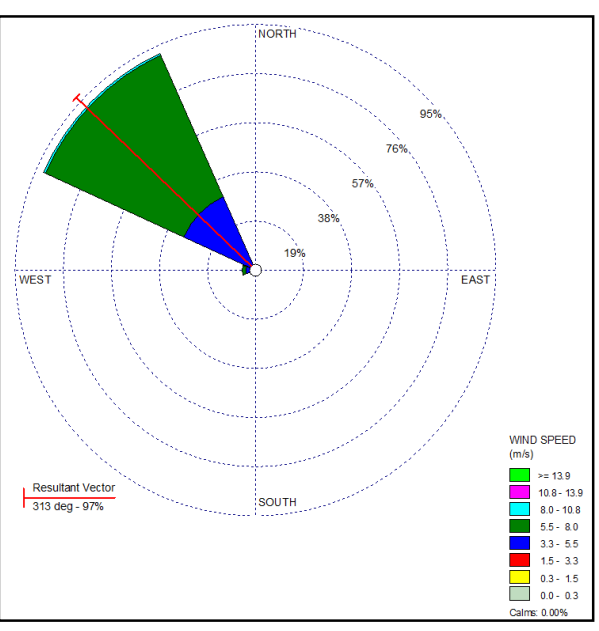

b.

Gambar 6. Mawar Angin a) Musim Barat Tahun 2018-2019 b) Musim Peralihan I Tahun 2018-2019

Gambar 6.b. menunjukkan mawar angin pada Musim Peralihan I tahun 2018-2019 dengan arah Utara, Timur Laut, Timur, Tenggara, Selatan dan Barat Daya memiliki nilai kecepatan angin pembangkit gelombang sebesar 0\%. Arah Barat memiliki kecepatan 5.5-8.0 m/s sebesar $1.51515 \%$ dan kecepatan angin $>8.0 \mathrm{~m} / \mathrm{s}$ sebesar 0\%. Arah Barat Laut memiliki kecepatan 5.5-8.0 m/s sebesar 59.8485\% dan kecepatan $>8.0$ sebesar $0.75758 \%$. Kecepatan angin pembangkit gelombang dengan nilai terbesar adalah arah Barat Laut, yaitu 60.60608\%. Arah Barat Laut juga memiliki frekuensi kecepatan angin terbesar yaitu 91.6667\% sehingga arah resultan kecepatan angin yaitu arah Barat Laut (N 313 $\left.{ }^{\circ} \mathrm{E}\right)$.

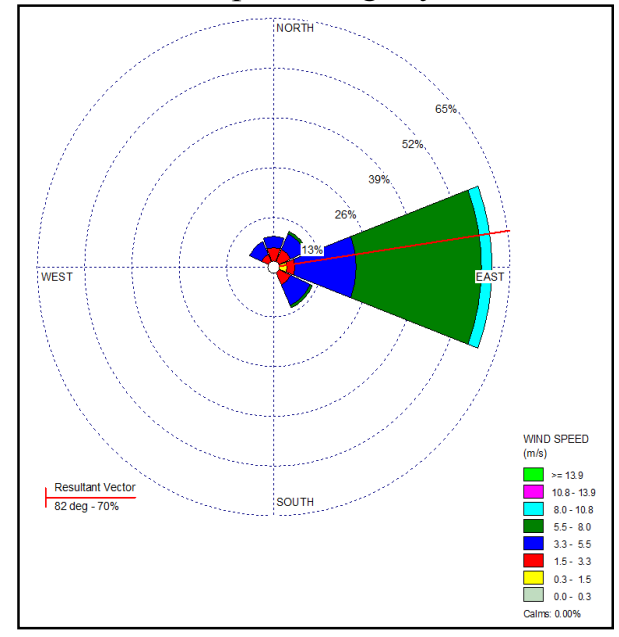

a.

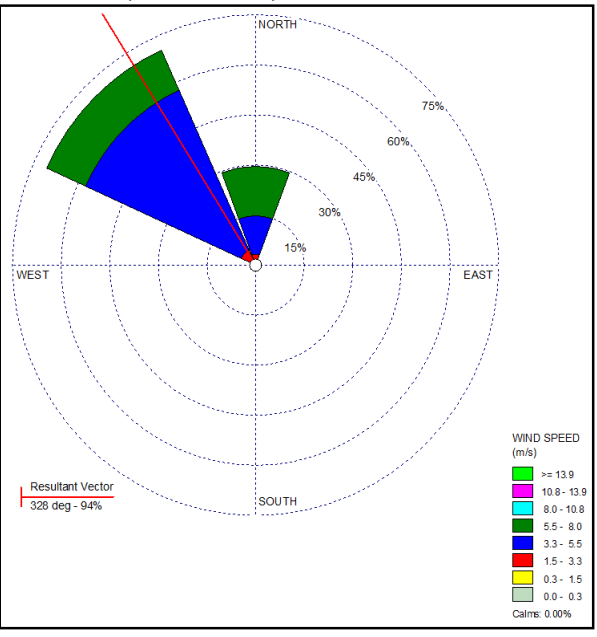

b.

Gambar 7. Mawar Angin a) Musim Timur Tahun 2018-2019 b) Musim Peralihan II Tahun 2018-2019 
Mawar angin Musim Timur 2018-2019 ditunjukkan pada Gambar 7.a. dengan arah Utara, Tenggara, Selatan, Barat Daya, Barat dan Barat Laut memiliki kecepatan angin pembangkit gelombang sebesar $0 \%$. Arah Timur Laut dengan kecepatan angin 5,5-8,0 m/s sebesar 0,73529\% dan kecepatan angin $>8,0 \mathrm{~m} / \mathrm{s}$ sebesar $0 \%$. Arah Timur kecepatan angin pembangkit gelombang dengan nilai 5,5-8,0 $\mathrm{m} / \mathrm{s}$ sebesar $33,8235 \%$ dan $>8,0 \mathrm{~m} / \mathrm{s}$ sebesar $2,94118 \%$. Arah resultan kecepatan angin adalah arah Timur $\left(\mathrm{N} 82^{\circ} \mathrm{E}\right)$, frekuensi kecepatan angin pembangkit gelombang dan kecepatan angin total adalah arah Timur dengan nilai 36,76468\% dan 59,5588\%.

Mawar angin Musim Peralihan II tahun 2019 pada Gambar 7.b. menginterpretasikan bahwa kecepatan angin pembangkit gelombang sebesar $0 \%$ arah Timur Laut, Timur, Tenggara, Selatan, Barat Daya dan Barat. Arah Barat Laut memiliki kecepatan 5.5-8.0 m/s sebesar 13.1148\% dan kecepatan $>8.0$ $\mathrm{m} / \mathrm{s}$ sebesar 0\%. Arah Utara kecepatan 5.5-8.0 m/s sebesar $14.7541 \%$ dan kecepatan $>8.0 \mathrm{~m} / \mathrm{s}$ sebesar $0 \%$. Frekuensi kecepatan angin pembangkit gelombang terbesar adalah arah Utara sebesar $14.7541 \%$ sedangkan frekuensi kecepatan angin total terbesar yaitu arah Barat Laut yaitu 70.4918\%. Arah resultan kecepatan angin dominan adalah arah Barat Laut $\left(\mathrm{N} 328^{\circ} \mathrm{E}\right)$.

\section{Gelombang}

Data gelombang yang diperoleh dari Badan Meteorologi, Klimatologi dan Geofisika Pusat diolah dengan metode gelombang representatif yang menghasilkan nilai tinggi gelombang representatif $\left(\mathrm{H}_{33}\right)$ dan periode gelombang representatif $\left(\mathrm{T}_{33}\right)$. Penentuan nilai gelombang representatif ini dengan mengambil rata-rata 33,3\% dari keseluruhan data yang telah diurutkan dari nilai yang terbesar ke terkecil (Triatmodjo 1999).

Tabel 3. Ketinggian Gelombang

\begin{tabular}{ccccc}
\hline & \multicolumn{4}{c}{ Tinggi Gelombang $(\mathrm{m})$} \\
\cline { 2 - 5 } & Min & Max & $\mathrm{H}_{33}$ & Rata-Rata \\
\hline Musim Barat & 1,20 & 2,50 & 2,29 & 1,94 \\
Musim Peralihan I & 1,30 & 2,30 & 1,96 & 1,67 \\
Musim Timur & 1,60 & 3,40 & 2,93 & 2,25 \\
Musim Peralihan II & 1,40 & 2,50 & 2,12 & 1,81 \\
\hline
\end{tabular}

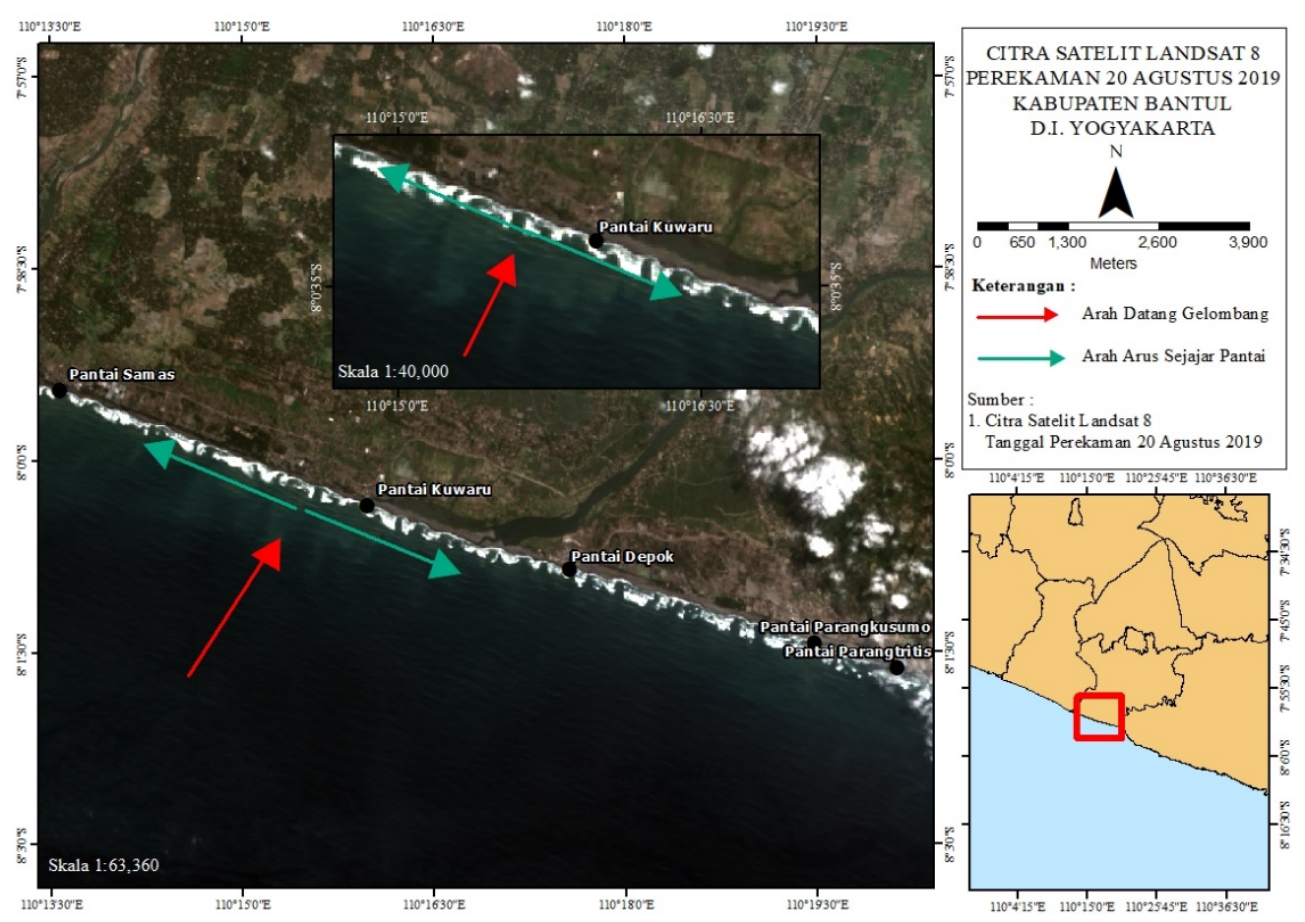


Gambar 8. Arah Datang Gelombang Berdasarkan Citra Satelit Landsat 8 Tahun 2019

Tabel 4. Periode Gelombang

\begin{tabular}{ccccc}
\hline & \multicolumn{4}{c}{ Periode Gelombang $(\mathrm{s})$} \\
\cline { 2 - 5 } & Min & Max & $\mathrm{T}_{33}$ & Rata-Rata \\
\hline Musim Barat & 8,00 & 13,00 & 9,90 & 10,55 \\
Musim Peralihan I & 9,00 & 14,00 & 12,60 & 11,71 \\
Musim Timur & 11,00 & 16,00 & 14,60 & 13,71 \\
Musim Peralihan II & 10,00 & 14,00 & 12,50 & 12,16 \\
\hline
\end{tabular}

Hasil interpretasi citra satelit Landsat 8 tanggal 20 Agustus 2019 (Gambar 8) menunjukkan bahwa arah datang gelombang terjadi dari arah Barat Daya menuju garis pantai sehingga menimbulkan terjadinya arus yang sejajar garis pantai dengan arah Tenggara dan Barat Laut.

\section{E. Perubahan Garis Pantai}

Citra Satelit Landsat 8 yang digunakan adalah perekaman tahun 2014, 2017 dan 2019 yang diolah dengan menggunakan perangkat lunak ArcGIS. Analisa perubahan garis pantai menggunakan metode DSAS (Digital Shoreline Analysis System) dengan perhitungan EPR (End Point Rate) dan NSM (Net Shoreline Movement) sehingga dapat dianalisis lebih lanjut untuk menentukan abrasi maupun akresi yang terjadi.

Tabel 5. Laju Perubahan Garis Pantai

\begin{tabular}{ccccc}
\hline \multirow{2}{*}{ Tahun } & \multicolumn{3}{c}{ EPR $($ End Point Rate) $(\mathrm{m} /$ tahun $)$} \\
\cline { 2 - 5 } & \multirow{2}{*}{ Tertinggi } & \multirow{2}{*}{ Terendah } & \multicolumn{2}{c}{ Rata - Rata } \\
\cline { 3 - 5 } & & & Akresi $(+)$ & Abrasi $(-)$ \\
\hline $2014-2017$ & 31,670 & $-48,140$ & 8,557 & $-12,075$ \\
$2017-2019$ & 34,210 & $-35,070$ & 10,091 & $-13,399$ \\
\hline
\end{tabular}

Tabel 6. Jarak Perubahan Garis Pantai (Net Shoreline Movement)

\begin{tabular}{|c|c|c|c|c|}
\hline \multirow{3}{*}{ Tahun } & \multicolumn{4}{|c|}{ NSM (Net Shoreline Movement) $(\mathrm{m})$} \\
\hline & \multirow{2}{*}{ Tertinggi } & \multirow{2}{*}{ Terendah } & \multicolumn{2}{|c|}{ Rata - Rata } \\
\hline & & & Akresi (+) & Abrasi (-) \\
\hline 2014-2017 & 95,690 & $-145,480$ & 25,857 & $-36,489$ \\
\hline 2017-2019 & 76,480 & $-78,390$ & 22,556 & $-29,954$ \\
\hline
\end{tabular}

Tabel 7. Luas Total Perubahan

\begin{tabular}{ccc}
\hline \multirow{2}{*}{ Tahun } & \multicolumn{2}{c}{ Luas Area (ha) } \\
\cline { 2 - 3 } & Akresi & Abrasi \\
\hline $2014-2017$ & 18,629 & 27,159 \\
$2017-2019$ & 14,835 & 21,903 \\
\hline
\end{tabular}

Hasil tersebut menyatakan bahwa tahun 2014-2017 luas daerah yang mengalami abrasi lebih besar serta tahun 2017-2019 luas daerah yang mengalami abrasi juga lebih besar dibandingkan dengan nilai luas daerah akresi. Analisis statistik perubahan garis pantai menunjukkan bahwa abrasi lebih dominan terjadi di pesisir Kabupaten Bantul. 


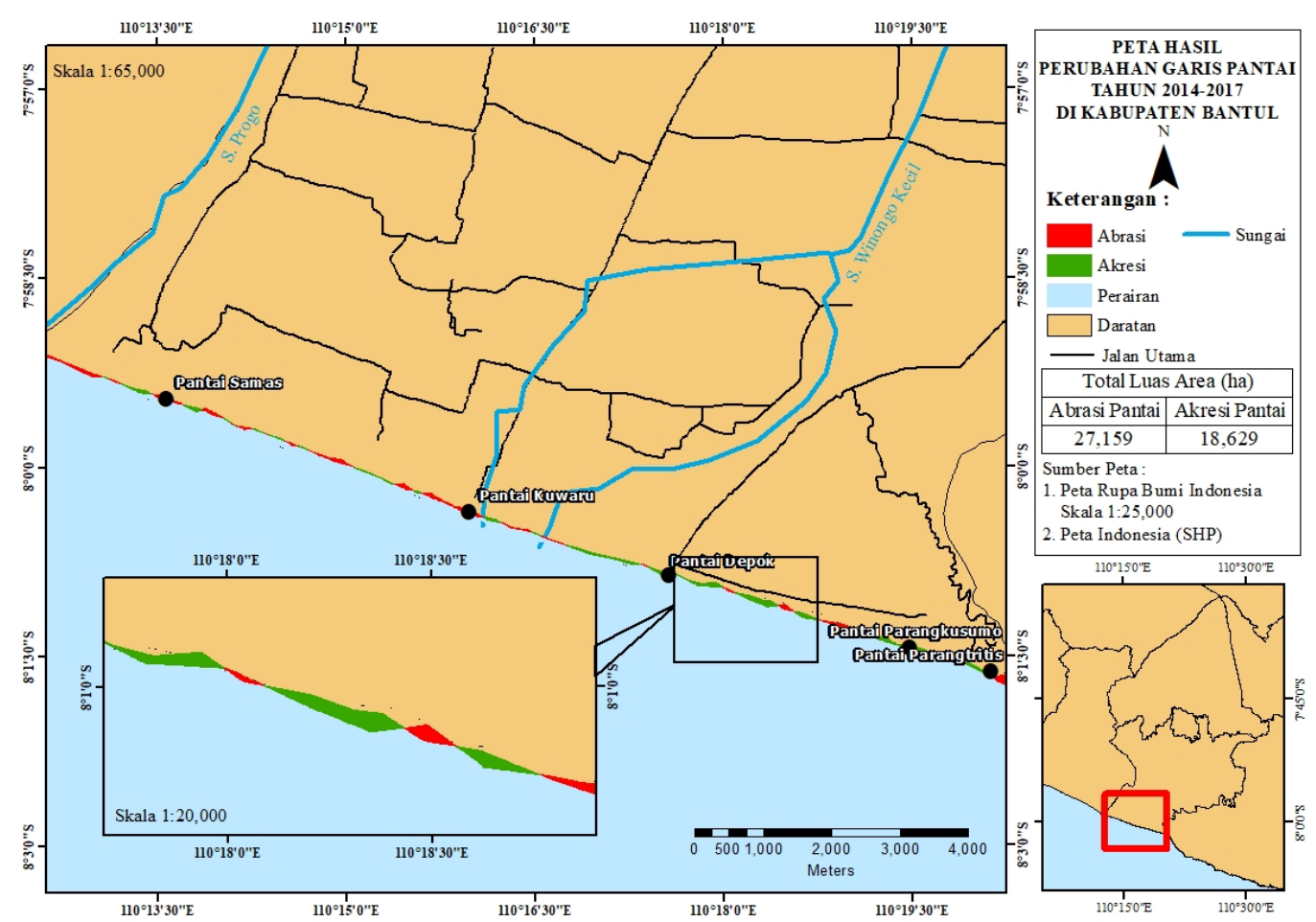

Gambar 9. Peta Perubahan Garis Pantai Tahun 2014-2017
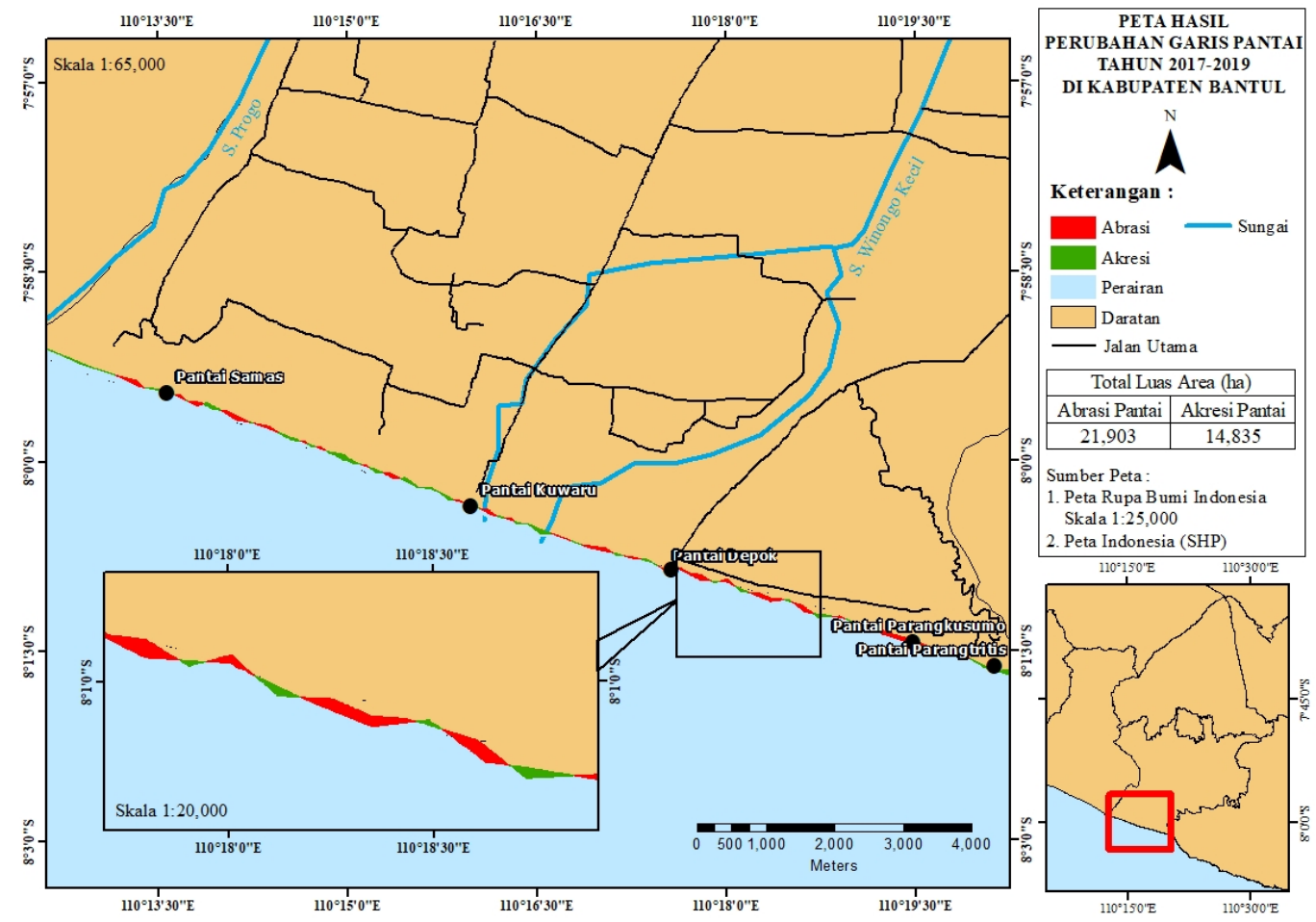

Gambar 10. Peta Perubahan Garis Pantai Tahun 2017-2019

Faktor hidro-oseanografi yang mempengaruhi terjadinya abrasi adalah kelerengan pantai yang bernilai curam dipengaruhi oleh faktor energi gelombang yang menghantam pesisir sehingga garis pantai akan tergerus dan mengakibatkan garis pantai mengalami abrasi. Kondisi pasang surut dengan 
tipe pasang surut harian tunggal juga memiliki dampak terhadap gelombang. Berdasarkan hasil pengolahan data, nilai elevasi muka air tinggi, ketinggian gelombang akan semakin tinggi sedangkan apabila nilai elevasi muka air rendah, maka nilai ketinggian gelombang juga semakin rendah. Pengolahan data tahun 2019 menunjukkan pada musim peralihan 2 nilai elevasi muka air tertinggi sebesar 116,2 cm dengan ketinggian gelombang maksimum sebesar $2,5 \mathrm{~cm}$ sedangkan musim peralihan 1 nilai elevasi muka air tertinggi sebesar $107,5 \mathrm{~cm}$ dengan ketinggian gelombang maksimum sebesar $2,3 \mathrm{~cm}$. Kondisi lokasi penelitian yang berada di perairan terbuka, yaitu berbatasan langsung dengan Samudera Hindia mengakibatkan pengaruh energi gelombang yang dibangkitkan oleh angin menjadi besar. Angin dominan berhembus dari arah Barat Laut yang akan membangkitkan gelombang dari arah barat laut menuju pesisir. Berdasarkan keseluruhan hasil pengolahan data, pada tahun 2014-2017 laju perubahan abrasi lebih besar dibandingkan dengan laju perubahan akresi sehingga jarak perubahan abrasi juga lebih besar dibandingkan dengan akresi. Nilai laju perubahan dan jarak perubahan abrasi yang besar ini mempengaruhi luas total area yang dominan mengalami abrasi. Sedangkan tahun 20172019 laju perubahan yang dominan adalah laju abrasi, nilai jarak perubahan yang lebih besar adalah jarak abrasi. Hal ini mengakibatkan luas total area yang dominan adalah luas total abrasi. Sehingga dapat disimpulkan bahwa pada tahun 2014-2017 dan 2017-2019 pesisir Kabupaten Bantul dominan mengalami abrasi.

\section{KESIMPULAN}

Luas perubahan garis pantai diperoleh dari hasil interpretasi citra Satelit Landsat 8 dengan metode DSAS, didapatkan pada tahun 2014-2017 luas total area yang terkena abrasi adalah 27,159 ha dan luas yang terkena akresi adalah 18,629 ha. Sedangkan pada tahun 2017-2019, luas total area yang mengalami abrasi adalah 21,903 ha dan yang mengalami akresi adalah 14,835 ha. Faktor yang mengakibatkan terjadinya abrasi yang dominan terjadi di Kabupaten Bantul adalah kondisi kelerengan pantai yang curam sehingga gelombang yang dibangkitkan angin pecah di daerah dekat garis pantai kemudian menimbulkan arus sejajar pantai yang menggerus garis pantai.

\section{DAFTAR PUSTAKA}

Badan Pusat Statistik Kabupaten Bantul. 2018. Kabupaten Bantul dalam Angka 2018. CV. Lunar Media Sejahtera, Yogyakarta.

Halim, Halili dan L.O.A. Afu. 2016. Studi Perubahan Garis Pantai dengan Pendekatan Penginderaan Jauh di Wilayah Pesisir Kecamatan Soropia. Jurnal Sapa Laut, 1(1):24 31.

Hidayat, N. 2005. Kajian Hidro-Oseanografi untuk Deteksi Proses-Proses Fisik di Pantai. Jurnal SMARTek, 3(2):73-85.

Stewart, R. H. 2008. Introduction To Physical Oceanography.Department of Oceanography Texas $A \& M$ University, Texas, $313 \mathrm{p}$.

Triatmodjo, B. 1999. Teknik Pantai. Beta Offset, Yogyakarta.

Van Zuidam, R.A. 1985. Aerial Photo-Interpretation in Terrain Analysis and Geomorphology Mapping. Smith Publisher The Hague, ITC. 